\title{
Resilience assessment: a useful approach to navigate urban sustainability challenges
}

\author{
My M. Sellberg ${ }^{1}$, Cathy Wilkinson ${ }^{1}$ and Garry D. Peterson ${ }^{1}$
}

\begin{abstract}
Cities and towns have become increasingly interested in building resilience to cope with surprises, however, how to do this is often unclear. We evaluated the ability of the Resilience Assessment Workbook to help urban areas incorporate resilience thinking into their planning practice by exploring how a resilience assessment process complemented existing planning in the local government of Eskilstuna, Sweden. We conducted this evaluation using participant observation, semistructured interviews, and a survey of the participants. Our findings show that the resilience assessment contributed to ongoing planning practices by addressing sustainability challenges that were not being addressed within the normal municipal planning or operations, such as local food security. It bridged longer term sustainable development and shorter term crisis management, allowing these two sectors to develop common strategies. Our study also highlighted that the Resilience Assessment Workbook could be made more useful by providing more guidance on how to practically deal with thresholds and trade-offs across scales, as well as on how to manage transdisciplinary learning processes. This is the first in-depth study of a resilience assessment process, and it demonstrates that the Resilience Assessment Workbook is useful for planning and that it merits further research and development.
\end{abstract}

Key Words: crisis management; Eskilstuna; local government planning; participatory processes; resilience assessment; sustainable development; Sweden; transdisciplinary research; urban planning

\section{INTRODUCTION}

Cities and local governments have recently become interested in building resilience (Evans 2011, Wilkinson 2012a). Many local governments and cities have a history of planning for disasters and sustainability (UNISDR 2007, ICLEI 2013), however the financial shocks following 2008, rising energy prices, and an increased awareness of climate change impacts have increased interest in resilience as a mechanism to cope with surprise (Shaw 2012). Resilience theory has developed to address such situations where control is weak and uncertainty high (Holling 1986, Peterson et al. 2003a) and the concept refers to a system's longterm ability to cope with change and continue to develop (Stockholm Resilience Centre 2014). This interest in resilience has led to new initiatives targeting local governments and cities, ranging from the UN's campaign of "Making cities resilient" (UNISDR 2012), and Rockefeller Foundation's "100 resilient cities" (2015), to bottom-up initiatives, such as transition towns, focusing on building resilience of local communities (Hopkins 2011). There has also been a growing interest in resilience thinking within urban planning disciplines (Wilkinson 2012b). All this activity raises the question of how resilience approaches complement existing planning practices of local governments, and in what ways they help urban planners address contemporary challenges? We identify new insights on what a resilience approach can offer urban planning practice.

We focus our attention on the Resilience Assessment Workbook (Resilience Alliance 2010). The workbook was developed by the Resilience Alliance and synthesizes their earlier work on how to apply resilience thinking (Walker et al. 2002). It is the only socialecological research initiative that operationalizes resilience for practitioners, and following its first release in 2007 it has been applied in multiple contexts around the world (Resilience Alliance 2013). Although it was originally aimed at natural resource managers, the workbook is also relevant for planning. The three key ideas behind the workbook are: (1) that the systems we manage are interlinked social-ecological systems, (2) these systems are complex and adaptive, and (3) they interact across scales in space and time (Resilience Alliance 2010). These ideas are increasingly being embraced in urban planning, but urban planning lacks tools to analyze these issues. For example, the dynamics of complex systems are neither included in mainstream sustainable development (Lélé 1998, Walker and Salt 2006), nor disaster relief approaches (Walker and Westley 2011). This lack of practical approaches to social-ecological complexity in urban planning suggests that the Resilience Assessment Workbook has the potential to contribute new tools and ideas.

However, because the Resilience Assessment Workbook has been primarily applied in natural resource management contexts, there is a lack of examples and guidance for applying it to urban areas. In general, the social-ecological research community has focused on operationalizing resilience in ecosystem management (Peterson et al. 2003a, Bennett et al. 2005, Biggs et al. 2012), and there are few empirical studies of how a resilience approach could inform urban planning processes (Wilkinson 2012b). There are few published studies of resilience assessments in general (e.g., Haider et al. 2012, Mitchell et al. 2014), and the few scholars who have applied the workbook to urban contexts find both strengths in how it, for example, integrated diverse sectors in local government planning (Wilkinson 2012a), as well as difficulties, e.g., in applying threshold effects to complex urban systems (Liu 2011). Paul Ryan, an expert practitioner of resilience assessments, has found the method more difficult to use in urban regions (Paul Ryan, May 2012, personal communication). Furthermore, none of the limited research on resilience assessment has thoroughly evaluated how the resilience assessment complements and conflicts with existing planning approaches. 
To address this research need, we performed the first in-depth assessment of an initial application of the Resilience Assessment Workbook in the Swedish municipality of Eskilstuna. By identifying how the resilience assessment complemented ongoing municipal planning practices, we build on Wilkinson's (2012c) earlier work to adapt the resilience assessment process to a planning context. Eskilstuna is typical of most European municipalities in that it has trained staff that is engaged in a variety of state mandated planning and management activities. At the beginning of the resilience assessment, the initiators at the municipality expected it to partially overlap with their ongoing work on sustainable development and crisis management. Nevertheless, they expected the assessment to contribute new ideas. Therefore, Eskilstuna offered the opportunity to address the research question: How can a resilience assessment complement existing planning and management within a local government? Furthermore, to improve the usefulness of the workbook in urban planning settings we identified challenges that emerged when conducting the resilience assessment and propose possible ways the Resilience Assessment Workbook could be improved to address these challenges.

\section{CASE STUDY DESCRIPTION}

\section{Planning in Eskilstuna municipality}

Eskilstuna municipality is a middle-sized Swedish municipality that spans $1250 \mathrm{~km}^{2}$ located between two of Sweden's largest lakes, Lake Mälaren and Lake Hjälmaren (Fig. 1). To the east, Lake Mälaren connects to the Baltic Sea through the Swedish capital, Stockholm, which is located about $100 \mathrm{~km}$ to the east. The biggest city in the municipality, with about two thirds of the municipality's 100,000 inhabitants, is also named Eskilstuna (Fig. 2).

Fig. 1. Eskilstuna municipality in Sweden. The municipality borders Lake Mälaren to the north and Lake Hjälmaren to the west. The biggest city, also called Eskilstuna, is situated in the middle of the municipality. The grey areas are urban, whereas the rest of the municipality is a mix of forested and agricultural land.

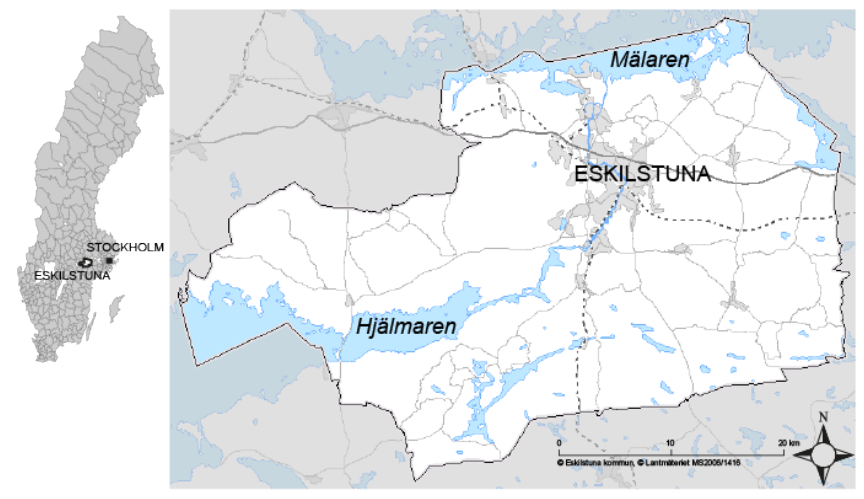

We focus on two areas of municipal planning, which the planners thought overlapped with the resilience assessment: planning for sustainable development and crisis management. Eskilstuna's commitment to sustainable development is beyond the Swedish average. The municipality is a former center of heavy industry that has reinvented itself (Fig. 2). In 2012, Eskilstuna received an award for being the "Environmentally Best Swedish Municipality" of the year (Miljöaktuellt 2012). Although the municipality adopted a sustainable development policy in 2002 (Eskilstuna kommun 2002), it is still struggling with how to implement it. In practice, planning for sustainable development primarily occurs in two types of planning: strategic environmental planning and comprehensive planning. Strategic environmental planning deals with many sustainable development issues, but it is applied separately to different sectors and topics; for example, a traffic plan is separate from a climate change plan (see a list of official municipal documents in Appendix 1). Swedish municipalities are required to develop a comprehensive plan to guide physical planning and these plans are a key element of the Swedish planning system (Schulman and Böhme 2000). Eskilstuna's comprehensive plan better integrates different sectors within sustainable development (Eskilstuna kommun 2005), but is limited to issues related to land and water use. In Sweden, municipalities have the main responsibility for physical planning (Böhme 2001). Compared with the rest of Europe, local authorities have more power in Nordic countries.

Fig. 2. The City of Eskilstuna. The Eskilstuna River flows through the city, connecting the two lakes, Hjälmaren and Mälaren. The river as a trading route contributed to making this an attractive area for settlements, for over 3000 years. From the 16th century the river became a source of power for the metal industry, for which the City of Eskilstuna became a center. The industry declined after structural changes in the 1970s, and lately, a hotel, restaurants, an art museum, and a sports arena have moved into the old industrial buildings, some of which are shown in this photo. Photo by Göran Jonsson, Eskilstuna municipality.

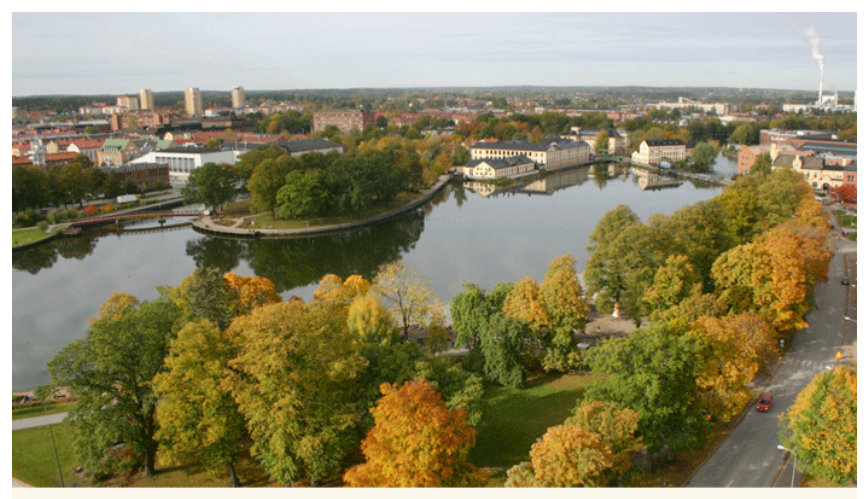

Municipal crisis management is compulsory by Swedish law (SFS 2006:544; Swedish Parliament 2006) and it requires preparedness for disasters, such as floods and infrastructure breakdowns, as well as disaster risk reduction. The focus is on maintaining critical societal functions in the face of these events. Crisis management functions across departments in the municipality, but at the time of this study there was no cooperation between crisis management and planning for sustainable development. However, the crisis manager could identify shared issues with sustainable 
development, especially in the area of climate change adaptation (Mats Löwenberg, November 2012, personal communication).

\section{Eskilstuna's initial resilience assessment}

Eskilstuna municipality prides itself on being a leader in environmental sustainability and part of being at the forefront involves always looking for ways to improve its environmental work. In this spirit, two of the municipality's environmental planners, Lars Wiklund and Lars-Erik Dahlin, pursued an interest in exploring how resilience could be applied in the municipality. In particular, they were concerned that conventional planning was not addressing how global threats, such as climate change, peak oil, financial crises, and the challenge of staying within planetary boundaries (Rockström et al. 2009), would affect local food and water supply, transport, and employment. In 2011, they contacted the Stockholm Resilience Centre to initiate a collaboration.

We address the first part of this collaboration, a process consisting of five planning meetings and an internal two-day workshop between August 2011 and February 2013. The two planners, together with Cathy Wilkinson and My Sellberg from Stockholm Resilience Centre, and Louise Hård af Segerstad, research communicator from Albaeco, formed the core planning team. This team used the Resilience Assessment Workbook and previous experience from resilience assessments to develop a workshop that addressed larger scale threats, as requested by the municipality, in a way that would be relevant for a planning context (Fig. 3). The team used Stockholm Resilience Centre's (2014) definition of resilience that includes both persistence and development as aspects of resilience, as does much resilience research (Holling 1986, Gunderson and Holling 2002, Walker and Salt 2006).

Fig. 3. The structure and scope of the resilience assessment in Eskilstuna municipality. Developed during the planning meetings with the two strategic environmental planners, Lars Wiklund and Lars-Erik Dahlin, as well as Cathy Wilkinson, Louise Hård af Segerstad, and My Sellberg. The municipality requested the content of the focal systems, specific threats, and impact dimensions. The project manager Cathy Wilkinson set the structure, which was based on the approach of Paul Ryan, an Australian expert practitioner of resilience assessments. The first two steps draw on section 1.1-1.3 in the Resilience Assessment Workbook (Resilience Alliance 2010).

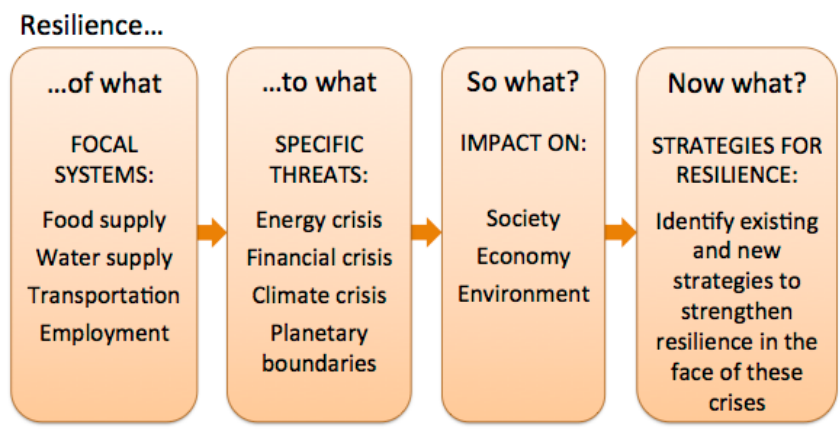

During the planning meetings, the planners set the focal systems and specific threats (Fig. 3). In the workshop, the 23 participants were divided into working groups for each focal system (Fig. 4) and went through exercises to increase their understanding of the focal systems as dynamic systems and spark ideas on measures to increase their resilience. The workshop was a first step, in which only internal representatives from the different departments and units were invited to participate. Most of the attendants were from the municipal office or the city planning administration. See Appendix 2 for a more detailed project description.

Fig. 4. The resilience assessment workshop in Eskilstuna. Louise Hård af Segerstad (research communicator) explaining an exercise to a group of civil servants discussing the transportation system. Project manager Cathy Wilkinson in the background adjusting the historical timeline. Photo by Lars Wiklund, Eskilstuna municipality.

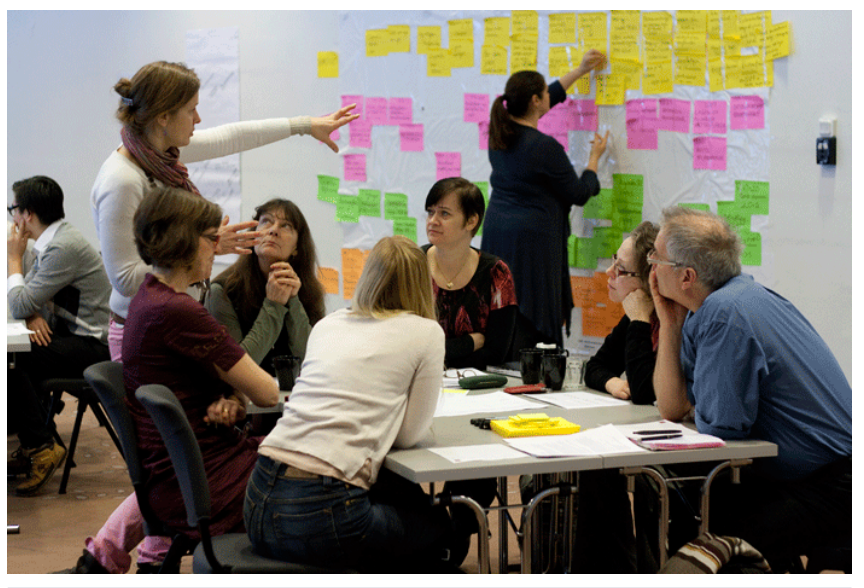

\section{METHODS}

\section{Assessing the assessment}

To evaluate Eskilstuna's resilience assessment we captured the participants' views of the process, rather than identifying policy changes, because of the limited scope of the study. Apart from contributions, challenges and limitations were also identified, where, e.g., a potential of the assessment was not realized. We did this by building upon Wilkinson's research on evaluating resilience in planning (Wilkinson 2012c). We adopted an in-depth case study design from interpretive policy analysis (Bevir and Rhodes 2006) that used textual analysis, participant observation, and in-depth interviews to provide a detailed understanding of beliefs of resilience assessment participants. Our data analysis was based on grounded theory, an inductive form of qualitative data analysis that enabled an ongoing dialogue between theory and the empirical world throughout the research process (Wagenaar 2011). My Sellberg collected the data and performed the majority of the analysis as a part of her master thesis (Sellberg 2013).

\section{Participant observations}

We participated in the five planning meetings and the final workshop, which took place in Eskilstuna and at Stockholm Resilience Centre. The participant observation allowed us to follow the process closely and gain a deeper understanding of the process outcomes and the reasons behind them. To document the observations, we wrote field notes (Jorgensen 1989). The reflection 
session in the end of the workshop was also recorded and transcribed.

All field notes included memos, which are informal notes of preliminary interpretations of the data and a key component of grounded theory methodology (Glaser 1998). Writing memos is a way to engage in the dialogue between our preliminary understandings and the empirical world from the beginning of the research process (Wagenaar 2011). Memos capture "comparisons and connections you make, and crystallize questions and directions for you to pursue" (Charmaz 2006:72). They help with focusing further data collection and developing coding categories (Wagenaar 2011).

\section{Semistructured interviews with key informants}

We interviewed six key informants: three strategic environmental planners, including the two initiators, one spatial planner, the crisis manager, and one Municipal Commissioner who supported the project. The key informants were chosen because they both had knowledge of one of the focus areas of municipal planning, i.e., crisis management, or planning for sustainable development, and were involved to different degrees in the project. Therefore, they could answer questions of, e.g., how the resilience assessment related to their usual work and what the challenges were with using it. The interviews were semistructured (Kvale and Brinkmann 2009), using an interview schedule with key topics (description in Appendix 3). All but two interviews were conducted face-to-face, recorded, and transcribed. The other two informants were interviewed by telephone, while taking notes.

\section{Survey}

The survey provided us with an additional source of data on the participants' views of the resilience assessment. Moreover, the survey allowed us to scan the views of all the workshop participants so that the individual accounts captured in the interviews could be set in a context. Of the 23 workshop participants, 20 took part in the survey. The survey was part of an evaluation form (Appendix 4) and used mainly open questions without fixed answering alternatives, to map the participants' views of the resilience assessment and their insights from the workshop (Esaiasson et al. 2007).

\section{Review of official documents}

To understand more of how the participants related the resilience assessment to their ongoing work, we reviewed current official municipal documents related to sustainability and crisis management. The documents were, e.g., strategic environmental plans for different sectors and a crisis management plan (Appendix 1). We compiled information on the main content of each document, its connections to the focus areas of the assessment (Fig. 3), and relations to the key ideas of the resilience assessment.

\section{Data analysis}

Following the strategy of grounded theory, we coded the data into categories to move from "empirical material to generalizations" (Wagenaar 2011:261). First, we separated the data on contributions from data on challenges. Secondly, all the data was coded into categories based on themes that emerged while we reviewed the data multiple times, building on the memos written earlier in the research process. This was an iterative process of coding and recoding to find categories that both were readily applicable to the data, and provided explanation to it (Wagenaar 2011). The emergent themes on contributions (Appendix 5) were part of Sellberg 2013, but for this paper we also reviewed them to distill three main categories.

\section{RESULTS}

The participants of Eskilstuna's resilience assessment identified three main ways that the assessment contributed to existing municipal planning and management:

1. It provided a dynamic systems perspective;

2. It enabled a discussion about global and uncertain threats;

3. It helped implement and advance their sustainable development work.

All the identified themes of contributions of the resilience assessment, which these three categories build upon, are presented with examples in Appendix 5.

\section{A dynamic systems perspective}

The resilience assessment introduced a dynamic view of change (Appendix 5:2). Of the 20 survey respondents, 9 wrote that thinking of threshold effects was something new. Similarly, the interviews showed that threshold effects were new to crisis management and strategic environmental and comprehensive planning. One planner said that they are working with sustainable development, which he related to "closing loops and getting mechanisms to work," however the resilience assessment added "the idea of fluctuations and thresholds," which he considered critical for urban planning to take into account.

Furthermore, the resilience assessment necessitated a view of the municipality as an interconnected system across sectors and scales (Appendix 5:3 and 5). Nine of the survey respondents thought that the resilience assessment had a more comprehensive view (Appendix 5:5). The assessment drew particular attention to social-ecological interactions (Appendix 5:4), by framing ecological values "as a part of human welfare," and targeting both ecological and social issues of concern, such as eutrophication and unemployment.

This integrated systems perspective was significant for both crisis management and planning for sustainable development. According to the strategic environmental planners, the workshop encouraged integration within sustainable development by discussing how issues were connected to one another across sectors, e.g., how employment in Eskilstuna could be affected by climate change (Table 1). For the crisis manager, the assessment had a broader scope than crisis management by targeting the geographical area of the municipality, instead of only municipal services. Moreover, it addressed the underlying events rather than their secondary consequences, e.g., climate change rather than an isolated flooding event. It also emphasized strategies for resilient ecosystems, such as ecological diversity (Appendix 5:9), which are not currently addressed within crisis management. At the workshop, the crisis manager met with sustainable development planners and discussed change in the focal systems with common concepts (Appendix 5:7).

\section{Enabling a discussion about uncertain futures and crises}

The resilience assessment enabled a discussion about global and uncertain threats (Appendix 5:6). According to the initiating 
Table 1. Examples of the three main ways the participants considered the resilience assessment to contribute to existing planning at Eskilstuna municipality. The categories are based on a clustering of the themes in Appendix 5. Quotes are translated from Swedish by My Sellberg.

\begin{tabular}{|c|c|c|}
\hline Categories & Examples & $\begin{array}{l}\text { More examples in } \\
\text { Appendix } 5\end{array}$ \\
\hline $\begin{array}{l}\text { Providing a dynamic } \\
\text { systems perspective }\end{array}$ & $\begin{array}{l}\text { Strategic Environmental Planner 1: "I think that many there (at the workshop) thought it } \\
\text { was a more holistic approach. I think some also saw that there were links between the } \\
\text { different focal areas. One issue affects a different area, which invites collaboration naturally. } \\
\text { So it's a pretty good lesson to be drawn, that it becomes clear - we will not solve this issue } \\
\text { ourselves because it affects another sector of society. Therefore, I think resilience thinking } \\
\text { has the potential to highlight this particular holistic thinking in sustainable development. } \\
\text { Which otherwise easily turns into that environment, social aspects, and economics become } \\
\text { separate things, without them being discussed together." }\end{array}$ & Theme $2-5$ \\
\hline
\end{tabular}

Enabling a discussion about Environmental Inspector: "It is a systematic way to look at how it will work, if it all goes global and uncertain threats bad. It's very easy otherwise to focus on that we should go forward all the time. Often we think: 'this is how it should be, it'll be fine.' But it is not as obvious to look at what happens if it doesn't go as expected. So I think that the method has a great strength in itself."

Theme 1, 6, 8-9

Helping to implement and advance the sustainable development work

\author{
Strategic Environmental Planner 3: "It clarifies why it (business-as-usual) will not hold. And Theme 7, 10-14 \\ then we can also have an argument. If people say 'it doesn't matter if the oil price goes up, \\ we will get more efficient cars, they will only consume 0.1 and then it doesn't matter so \\ much, we are not vulnerable at all.' Then you can have a discussion about these thresholds \\ perhaps, and get some sense of how vulnerable we are, too. Perhaps we can agree on that. So \\ I think that would help actually."
}

planners, the municipality lacked preparedness for potential global crises. These issues had no clear organizational home and planning for worst-case scenarios was lacking. The workshop was used to discuss these issues, as well as the issue of local food security, none of which had previously been on the municipality's agenda.

Four key aspects facilitated the discussion on future threats. First, the resilience assessment encouraged a longer time perspective in planning, according to eight of the survey respondents. The crisis manager also considered the workshop to have a "much longer time horizon" than his work with crisis management. Second, the broad scope of the workshop enabled inclusion of areas outside of normal municipal services, such as food supply. Third, the idea of threshold effects helped to capture the risk of dramatic and undesired consequences of crises to society to which we cannot slowly adapt (Appendix 5:6 and 13). Finally, the assessment provided a mindset of assuming change and uncertainty (Appendix 5:1), which broadened the discussion of threats to include not only the most likely scenarios from today's perspective (Appendix 5:8). According to one of the participants, the workshop focused more on "what could happen, than on the normal state," and another described it as "a systematic way" of assessing whether the municipal plans would function even if "reality doesn't turn out as you had thought it would" (Table 1).

It is too early to tell how enabling this discussion will affect municipal planning. As of late 2014, the workshop has led to the planners continuing to work with resilience assessment, with a focus on local food security.

Implementing and advancing sustainable development work The resilience assessment supported the implementation of sustainable development in two ways. First of all, the method, with its focus on how sustainable a system is to a specific threat, was a new way of operationalizing sustainable development and "fill the concept ... with concrete content," according to the strategic environmental planners (Appendix 5:6 and 10). They already had, e.g., sustainability principles for operationalizing sustainable development (Natural Step 2013), but according to the planners, the concept was still perceived as vague by many of the civil servants. Second, the dynamic systems perspective helped integrate sectors within sustainable development, as explained in the first category. The planners experienced that implementation of sustainable development usually is carried out in silos by different departments, which was not the case with the resilience assessment. One of the initiators said that the workshop helped put "different parts of society's functions" in a context where they "get a more comprehensive assessment."

The strategic environmental planners also thought that the resilience assessment had the potential to advance their sustainability work (Appendix 5:13-14). For example, one planner stated that even though climate change is an accepted issue, little is actually being done to mitigate its impacts and the municipality continues building houses close to the water. In this context, the resilience assessment can motivate further measures toward sustainability, through the discussion of large-scale threats explained above, and by providing arguments for actions (Table 1). For example, the risk of abrupt threshold effects in apparently slow and "invisible" trends, such as eutrophication or segregation, provides stronger basis for taking action and investing resources in avoiding undesired states. One planner also mentioned that viewing society and nature as interconnected might enable investments in ecosystems as green infrastructure to address problems in other parts of society, rather than viewing ecological protection as a luxury. 


\section{Challenges and limitations}

Although the idea of threshold effects was new to the municipal planning practices, some participants also raised concerns about its applicability. Three survey respondents stated that even though the dynamic perspective was a key part of the workshop, it was difficult to apply to their focal areas, especially the less ecological ones, such as employment. In a workshop exercise, for example, the employment group discussed variables that could prevent or trigger a regime shift to a less desirable state with higher unemployment. However, unemployment in Eskilstuna is already higher than the Swedish average and one participant stated afterward that the exercise gave a sense of things getting worse, while they are actually working toward a positive development. The transportation group solved this by viewing transportation as a system that needs to transform to fossil-fuel independence and discussed, e.g., variables hindering that transformation. Afterward, the planners were uncertain if the thresholds discussed in the workshop actually existed and indicated the importance of threshold effects being scientifically identified.

At the workshop, we presented both the idea of cross-scale coordination, i.e., that "resilience at one scale cannot be achieved at the cost of resilience at lower or higher scales" (Wilkinson and Wagenaar 2012:4), and the concept of planetary boundaries (Rockström et al. 2009), even though they are not part of the workbook. The reason was to relate Eskilstuna's work to globalscale sustainability challenges. Nevertheless, one participant mentioned, for example, that her group had focused on Eskilstuna's interests, without discussing impacts on other municipalities or countries. Another participant stated that a resilience approach could call for a broadening of the streets in Eskilstuna City as a buffer toward traffic jams, which would conflict with the municipality's sustainability goal to decrease car use and subsequent carbon emissions. These examples show how a resilience assessment approach in practice risks being focused on the resilience of the focal system, without taking into account how it influences the resilience of other systems or scales. It also shows that cross-scale trade-offs are difficult to grasp and might require more attention in a workshop setting than our initial presentation.

The broad perspective of the workshop was evident to many of the participants, but the organizers still found it difficult to get a diverse set of people to participate. Neither economists, nor civil servants from the educational or cultural departments took part, even though they were invited. This was mentioned in the reflection round after the workshop. Four of the survey respondents also questioned the broad perspective of the workshop because it addressed areas where the municipality has little influence and knowledge, such as food supply. Nevertheless, the workshop highlighted the need to involve stakeholders in the process if they would continue working with food security issues.

Finally, the initiators acknowledged that this first workshop was mostly about learning the resilience assessment method and mindset and that further in-depth workshops were needed to develop proposals for new governance strategies. They referred this to the challenges of using a new and untried method and having little time to go deeper into broad issues. At the end of the workshop, earlier expectations from the initiators to come up with strategies for the municipality's long-term planning were not seen as reasonable within the limited timeframe.

\section{DISCUSSION}

In the results we presented the contributions of Eskilstuna's resilience assessment, according to the participants. Here we discuss how a resilience assessment can support a municipality's work with sustainable development and serve as a bridge to crisis management. We also conclude that the key ideas of the resilience assessment made a difference for the practitioners. In the end, we present some of the lessons learned from Eskilstuna's assessment and propose areas for improvement.

\section{New perspectives in the implementation of sustainable development}

The resilience assessment introduced new ideas to planning for sustainable development (Fig. 5). All the interviewed planners working with sustainable development stated that the resilience assessment added increased thinking about abrupt nonlinear changes and alternate regimes. This contribution corresponds to literature stating that the mainstream usage of sustainable development does not adequately consider system dynamics (Lélé 1998, Walker and Salt 2006). The method's focus on how a system can cope with change provided a new way of operationalizing sustainable development. Beneath this focus lies a mindset that assumes surprise and uncertainty, which scholars have argued is useful in times of looming crises (Davoudi 2012, Shaw 2012).

Fig. 5. Bridging sustainable development and crisis management. The resilience assessment overlapped partially both crisis management and planning for sustainable development, including both strategic environmental planning and comprehensive planning, in Eskilstuna municipality. However, the overlaps with sustainable development practices were new to crisis management, and vice versa. In this sense, the resilience assessment bridged planning for sustainable development and crisis management, which did not have any collaboration at the time of the study. The ideas of system dynamics were new to both aspects of municipal planning.

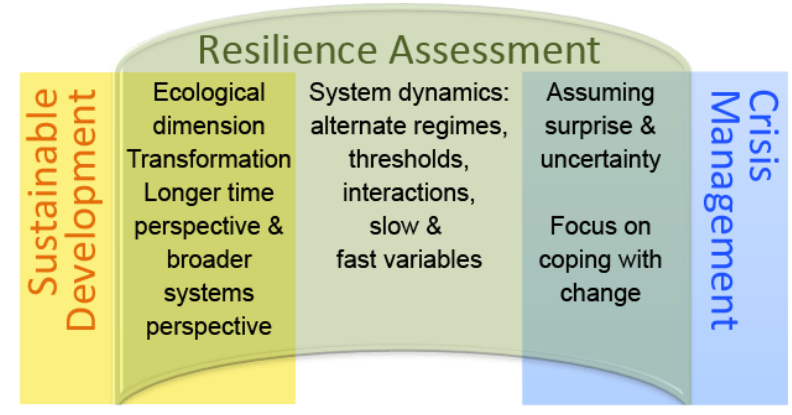

The resilience assessment also strengthened existing views within sustainable development, by re-emphasizing an integrated perspective. The Johannesburg Declaration, for example, highlights the interdependence of social, ecological, and economic dimensions, as well as our collective responsibility from local to global levels (WSSD and UN Department of Public Information 2003). However, this integration was difficult to pursue in practice, and therefore the contribution of the resilience assessment was important to the planners. Previously, resilience thinking has also been recognized for being able to connect phenomena that are isolated in different silos in mainstream 
planning (Porter and Davoudi 2012), such as ecology and urban design (Pickett et al. 2004), and provide a "common language across diverse sectoral and disciplinary interests" (Wilkinson 2012a:323).

Our findings confirm and expand on the idea that resilience assessment can be used to advance the work with sustainable development. Previously, metropolitan planners (Wilkinson et al. 2010), as well as social movement promoters (Hopkins 2009), have identified resilience as a potentially more powerful and useful concept than sustainability, e.g., for challenging status quo responses to urban problems, or finding systemic solutions to climate change. The Eskilstuna planners did not see resilience as a substitute for sustainability, but rather as an important complement, and they used the resilience assessment to bring previously ignored and complex sustainability issues up for discussion, such as how food security would be affected by future crises in energy, climate, and finances. This first workshop has led to a continued project on the resilience of the food system, a completely new area for municipal planning. This is similar to Luleå, where a resilience assessment served to frame the "deeper, more structural issues" and bring them to the planning agenda (Wilkinson 2012a:323).

\section{Expanding crisis management and bridging to sustainable development}

The resilience assessment partially overlapped with crisis management, but had a larger scope in time and space (Fig. 5). Resilience assessment's focus on how to handle change and uncertainty (Appendix 5:1) was not new to crisis management, but crisis management's focus was mostly limited to short-term crises in municipal services, rather than slow changes in ecosystems or society. The resilience assessment also introduced the idea of complex adaptive systems, corresponding to Walker and Westley's (2011) finding that the idea of complex adaptive systems with alternate regimes was rare within the disaster relief community.

Resilience assessment served as a bridge between crisis management and sustainable development (Fig. 5) because of its partial overlap with both of them. An example of the bridging function of the resilience assessment is the inclusion of both slow and fast changes. System dynamics, for example, examines interactions between slow and fast variables (Walker and Salt 2006). Currently crisis management is dealing with short-term shocks to the system, separated from strategic environmental and comprehensive planning, which focuses on longer term trends. A resilience approach could contribute to crisis management with attention to slow variables, corresponding to the conclusions of Walker and Westley (2011). Furthermore, it confirms the findings of Shaw and Maythorne (2012) that a resilience discourse could potentially integrate short- to medium-term emergency planning with medium- to long-term climate adaptation. The bridging function of the resilience assessment implies that it has the potential of providing local authorities with common strategies to handle change across sectors, in line with Shaw and Maythorne (2012).

\section{The key ideas of resilience assessment made a difference to practitioners}

The three key ideas of the resilience assessment made a difference to the participants in the project. For example, social-ecological systems and cross-scale interactions provided the comprehensive perspective necessary to integrate sectors in sustainable development planning. Moreover, complex adaptive systems gave a new dynamic perspective on change that bridged the short- and long-term perspectives of crisis management and planning for sustainable development, respectively. Compared to other approaches for operationalizing resilience in local governments, such as UNISDR (2012) and the Rockefeller Foundation (2013), the workbook has a stronger foundation in a theoretical framework, which emphasizes system dynamics, social-ecological feedbacks, resilience-building of ecosystems, and ecosystem services.

\section{Lessons for resilience assessments}

One of the benefits of testing a method in practice is that it clarifies possible areas for improvement. Based on our evaluation of an initial resilience assessment process in an urban planning setting we identify four weaknesses in the Resilience Assessment Workbook and suggest ways in which they could be addressed.

\section{Identifying thresholds in practice}

Even though the Eskilstuna planners found the concept of threshold effects useful, they were uncertain of whether the identified thresholds actually existed and found the concept less applicable to the focus areas of transport and employment. This points to two areas of the workbook that could be improved: (1) how to deal with uncertain thresholds, and (2) how to identify thresholds that are not biophysical. Regarding the first point, we suggest that the workbook could be improved by incorporating concepts from strategic adaptive management, which identify thresholds of potential concern and plans for how to regularly evaluate them (e.g., Biggs and Rogers 2003, Biggs et al. 2011, Roux and Foxcroft 2011), as well as Walker and Salt (2012), which includes a step process of how to identify thresholds with different degrees of uncertainty. For the second point, we suggest that the workbook should discuss this difficulty (following, e.g., Walker and Salt 2012) and suggest possible ways to navigate this process. For example, by viewing social thresholds in terms of what is collectively recognized as desirable or acceptable in a community (Christensen and Krogman 2012), or using scenario planning to explore system dynamics in complex systems in a broader sense (Walker et al. 2002, Peterson et al. 2003b). However, how to effectively identify thresholds in real world situations is an area that needs experimentation, research, and evaluation.

\section{Including local level responses to global challenges}

The Eskilstuna planners wanted to align the resilience assessment with their work with sustainable development, which includes dealing with global challenges, such as climate change mitigation. Nevertheless, the idea of cross-scale coordination was not always apparent in the discussions during the assessment. The idea that transformation of smaller scale systems can be needed to foster Earth System resilience exists in the resilience thinking framework (Folke et al. 2010), but is not included in interfaces with practice (Resilience Alliance 2010, Walker and Salt 2012). We propose that the workbook should give advice on how to address trade-offs between resilience on different scales. We also encourage resilience assessment practitioners to allow for more time to discuss crossscale trade-offs, possibly iteratively over several workshops, if this is considered to be an important part of the assessment. 
Missing guidance on design of participatory process

The workbook does not provide guidance on how to design, manage, and facilitate a participatory assessment process. This is surprising, considering that the predecessor of the workbook (Walker et al.2002) proposed a close involvement of stakeholders, and the workbook itself states that perspectives of multiple stakeholders are important for many of the exercises, e.g., in identifying the main issues. A participatory assessment process is necessary to successfully address complex issues (Wagenaar 2007, Bai et al. 2010) where no single actor has the knowledge to do the assessment, nor the influence to carry through the strategies resulting from it. A participatory process also holds the potential of enabling dialogue and social learning. The social-ecological inventory (Schultz et al. 2007) can help to identify actors to include in the process, but we suggest adding a discussion of process design to the workbook with different examples of processes and how they fit with different political and cultural contexts, as well as providing links to other resources on how to manage transdisciplinary learning processes (e.g., Scholz 2011).

\section{From learning to transformation}

The planners in Eskilstuna initiated the resilience assessment process because they were interested in learning how resilience could be applied in municipal planning. They also wanted to both safeguard current values in the face of change, and identify strategies for moving Eskilstuna toward a more sustainable future. These types of multiple goals are likely widely shared among those practicing resilience assessment and the workbook would be improved if it provided more guidance on how it could be used to meet different goals. For example, a resilience assessment process focused on training people to apply the method within a municipality has quite different goals than one focused on developing an implementation plan. Moreover, training participants to apply the method could initiate a longer engagement with resilience. This was the case in Eskilstuna municipality, which now is continuing the exploration of resilience with a focus on local food security. Relating to the suggestion above on process designs in different contexts, we suggest that the workbook also advise how the assessment process can be designed for different purposes, e.g., to quickly scan local resilience, conduct an in-depth assessment, or develop transformation strategies, as well as how these different steps could build on each other in a bigger process.

\section{CONCLUSION}

We found that the resilience assessment complemented ongoing municipal planning and management by operationalizing sustainable development in a way that integrated sectors and introduced a dynamic perspective on change. The resilience assessment was a useful tool and mindset to tackle sustainability challenges that were not being addressed within the normal municipal planning or operations. Resilience assessment built a bridge between longer term sustainable development and shorter term crisis management, allowing these two sectors to develop common strategies.

Our study of the practice of resilience assessment also highlighted that the Resilience Assessment Workbook could be made more useful by providing more guidance on how to practically deal with thresholds, as well as trade-offs across scales. Additionally, it could give more guidance on how to manage transdisciplinary learning processes and how to use the workbook for different goals.

In the Swedish context, Eskilstuna municipality is a sustainability leader, however, the resilience assessment further advanced its sustainability planning and practices. We therefore expect that resilience assessments are a potentially useful approach for other municipalities in Sweden, Europe, and elsewhere. We have presented the first in-depth study of a resilience assessment process and our results demonstrate that the resilience assessment approach is useful for planning, and we urge researchers to continue developing the Resilience Assessment Workbook and engage in local transdisciplinary learning processes, to create multiple versions for a diverse set of audiences and purposes.

Responses to this article can be read online at: http://www.ecologyandsociety.org/issues/responses. php/7258

\section{Acknowledgments:}

We would like to thank all the participants from Eskilstuna municipality for their courage and openness. We are especially grateful for having had the opportunity to work with Lars Wiklund, Lars-Erik Dahlin, and Kristina Birath at Eskilstuna municipality, as well as Louise Hård af Segerstad at Albaeco, in the cocreation of this resilience assessment process. We thank Jamila Haider and Allyson Quinlan for useful comments. This paper is based upon My Sellberg's master thesis Resilience in Practice for Strategic Planning at a Local Government in Social-Ecological Resilience for Sustainable Development at Stockholm University (Sellberg 2013).

\section{LITERATURE CITED}

Bai, X., R. R. J. McAllister, R. M. Beaty, and B. Taylor. 2010. Urban policy and governance in a global environment: complex systems, scale mismatches and public participation. Current Opinion in Environmental Sustainability 2:129-135. http://dx.doi. org/10.1016/j.cosust.2010.05.008

Bellwood, D. R., T. P. Hughes, C. Folke, and M. Nyström. 2004. Confronting the coral reef crisis. Nature 429:827-833. http://dx. doi.org/10.1038/nature02691

Bennett, E. M., G. S. Cumming, and G. D. Peterson. 2005. A systems model approach to determining resilience surrogates for case studies. Ecosystems 8:945-957. http://dx.doi.org/10.1007/ s10021-005-0141-3

Bevir, M., and R. A. W. Rhodes. 2006. Governance stories. Routledge, London, UK.

Biggs, H., S. Ferreira, S. Freitag-Ronaldson, and R. Grant-Biggs. 2011. Taking stock after a decade: does the 'thresholds of potential concern' concept need a socio-ecological revamp? Koedoe 53:2. http://dx.doi.org/10.4102/koedoe.v53i2.1002

Biggs, H. C., and K. H. Rogers. 2003. An adaptive system to link science, monitoring, and management in practice. Pages 59-80 in J. T. Du Toit, K. H. Rogers, and H. C. Biggs, editors. The Kruger 
experience: ecology and management of savanna heterogeneity. Island Press, Washington, D.C., USA.

Biggs, R., M. Schlüter, D. Biggs, E. L. Bohensky, S. BurnSilver, G. Cundill, V. Dakos, T. M. Daw, L. S. Evans, K. Kotschy, A. M. Leitch, C. Meek, A. Quinlan, C. Raudsepp-Hearne, M. D. Robards, M. L. Schoon, L. Schultz, and P. C. West. 2012. Toward principles for enhancing the resilience of ecosystem services. Annual Review of Environment and Resources 37(1):421-448. http://dx.doi.org/10.1146/annurev-environ-051211-123836

Böhme, K. 2001. Spatial planning in the light of Nordic eccentricity. Built Environment 27(4):295-303.

Charmaz, K. 2006. Constructing grounded theory: a practical guide through qualitative analysis. Sage, Thousand Oaks, California, USA.

Christensen, L., and N. Krogman. 2012. Social thresholds and their translation into social-ecological management practices. Ecology and Society 17(1): 5. http://dx.doi.org/10.5751/ ES-04499-170105

Davoudi, S. 2012. Resilience: a bridging concept or a dead end? Planning Theory and Practice 13(2):299-307. http://dx.doi. org/10.1080/14649357.2012.677124

Esaiasson, P., M. Gilljam, H. Oscarsson, and L. Wängnerud. 2007. Frågeundersökningar. Pages 257-281 in P. Esaiasson, M. Gilljam, H. Oscarsson, and L. Wängnerud, editors. Metodpraktikan: konsten att studera samhälle, individ och marknad. Third edition. Norstedts Juridik, Stockholm, Sweden.

Eskilstuna kommun. 2002. Miljöpolicy för Eskilstuna kommun. Eskilstuna, Sweden. [online] URL: http://www.eskilstuna.se/ PageFiles $/ 35336 / \mathrm{milj}^{2} \% \mathrm{C} 3 \%$ B6policy $\% 20$ en $\% 20$ sida.pdf?epslanguage $=$ $\underline{\mathrm{SV}}$

Eskilstuna kommun. 2005. Översiktsplanering 2005. Eskilstuna, Sweden. [online] URL: http://www.eskilstuna.se/sv/Bygga-booch-miljo/Stadsplanering-och-byggande/Planera/Oversiktsplanering/

Evans, J. P. 2011. Resilience, ecology and adaptation in the experimental city. Transactions of the Institute of British Geographers 36(2):223-237. http://dx.doi.org/10.1111/

j.1475-5661.2010.00420.x

Folke, C., S. R. Carpenter, B. Walker, M. Scheffer, T. Chapin, and J. Rockström. 2010. Resilience thinking: integrating resilience, adaptability and transformability. Ecology and Society 15(4): 20. [online] URL: http://www.ecologyandsociety.org/vol15/iss4/ art20/

Glaser, B. G. 1998. Doing grounded theory: issues and discussions. Sociology Press, Mill Valley, California, USA.

Gunderson, L., and C. S. Holling, editors. 2002. Panarchy: understanding transformations in human and natural systems. Island Press, Washington, D.C., USA.

Haider, L. J., A. E. Quinlan, and G. D. Peterson. 2012. Interacting traps: resilience assessment of a pasture management system in northern Afghanistan. Planning Theory and Practice 13 (2):312-319. http://dx.doi.org/10.1080/14649357.2012.677124

Holling, C. S. 1986. The resilience of terrestrial ecosystems: local surprise and global change. Pages 292-320 in W. C. Clark and R.
E. Munn, editors. Sustainable development of the biosphere Cambridge University Press, Cambridge, UK.

Hopkins, R. 2009. Resilience thinking: why 'resilience thinking' is a crucial missing piece of the climate-change jigsaw. Resurgence 257:12-15.

Hopkins, R. 2011. The transition companion: making your community more resilient in uncertain times. Chelsea Green, White River Junction, Vermont, USA.

ICLEI (Local Governments for Sustainability). 2013. Our members. ICLEI, Bonn, Germany. [online] URL: http://www. iclei.org/our-members.html

Jorgensen, D. L. 1989. Participant observation. Sage, Thousand Oaks, California, USA.

Kvale, S., and S. Brinkmann. 2009. Interviews: learning the craft of qualitative research interviewing. Second Edition. Sage, Thousand Oaks, California, USA.

Lélé, S. 1998. Resilience, sustainability environmentalism. Environment and Development Economics 3(2):221-262. http://dx. doi.org/10.1017/S1355770X98260128

Liu, W. T. 2011. An application of the resilience assessment workbook on the town of Caledon, Ontario, Canada: resilience of what? Resilience to what? Resilience with what? Thesis. University of Waterloo, Waterloo, Ontario, Canada.

Miljöaktuellt. 2012. Så gjorde vi kommunrankningen 2012. 28 June. [online] URL: http://miljoaktuellt.idg.se/2.1845/1.456682/ sa-gjorde-vi-kommunrankningen-2012

Mitchell, M., R. Griffith, P. Ryan, G. Walkerden, B. Walker, V. A. Brown, and S. Robinson. 2014. Applying resilience thinking to natural resource management through a "planning-by-doing" framework. Society \& Natural Resources 27(3):299-314. http://dx. doi.org/10.1080/08941920.2013.861556

Natural Step. 2013. The four system conditions of a sustainable society. The Natural Step, Cheltenham, UK. [online] URL: http:// www.thenaturalstep.org/sv/the-system-conditions

Peterson, G. D., S. R. Carpenter, and W. A. Brock. $2003 a$. Uncertainty and the management of multistate ecosystems: an apparently rational route to collapse. Ecology 84(6):1403-1411. http://dx.doi.org/10.1890/0012-9658(2003)084[1403:UATMOM]2.0. $\underline{\mathrm{CO} ; 2}$

Peterson, G. D., G. S. Cumming, and S. R. Carpenter. $2003 b$. Scenario planning: a tool for conservation in an uncertain world. Conservation Biology 17(2):358-366. http://dx.doi.org/10.1046/ j.1523-1739.2003.01491.X

Pickett, S. T. A., M. L. Cadenasso, and J. M. Grove. 2004. Resilient cities: meaning, models, and metaphor for integrating the ecological, socio-economic, and planning realms. Landscape and Urban Planning 69(4):369-384. http://dx.doi.org/10.1016/j. landurbplan.2003.10.035

Porter, L., and S. Davoudi. 2012. The politics of resilience for planning: a cautionary note. Planning Theory and Practice 13 (2):329-333. http://dx.doi.org/10.1080/14649357.2012.677124 
Resilience Alliance. 2010. Assessing resilience in social-ecological systems: workbook for practitioners. Version 2.0. [online] URL: http://www.resalliance.org/3871.php

Resilience Alliance. 2013. Resilience Assessment. [online] URL: http://www.resalliance.org/index.php/resilience assessment

Rockefeller Foundation. 2013. Rebound: building a more resilient world. Rockefeller Foundation, New York, New York, USA. [online] URL: http://100resilientcities.rockefellerfoundation.org/ blog/entry/rebound-building-a-more-resilient-world

Rockefeller Foundation. 2015. 100 resilient cities. Centennial challenge. Rockefeller Foundation, New York, New York, USA. [online] URL: http://www.100resilientcities.org/\#/- /

Rockström, J., W. Steffen, K. Noone, A. Persson, F. S. Chapin III, E. F. Lambin, T. M. Lenton, M. Scheffer, C. Folke, H. J. Schellnhuber, B. Nykvist, C. A. de Wit, T. Hughes, S. van der Leeuw, H. Rodhe, S. Sörlin, P. K. Snyder, R. Costanza, U. Svedin, M. Falkenmark, L. Karlberg, R. W. Corell, V. J. Fabry, J. Hansen, B. Walker, D. Liverman, K. Richardson, P. Crutzen, and J. A. Foley. 2009. A safe operating space for humanity. Nature 461 (7263):472-475. http://dx.doi.org/10.1038/461472a

Roux, D. J., and L. C. Foxcroft. 2011. The development and application of strategic adaptive management within South African National Parks. Koedoe 53(2):01-05. http://dx.doi. org/10.4102/koedoe.v54i1.1049

Scholz, R. W. 2011. Environmental literacy in science and society: from knowledge to decisions. Cambridge University Press, New York, New York, USA. http://dx.doi.org/10.1017/CBO9780511921520

Schulman, M., and K. Böhme. 2000. New dynamics in a municipal-based planning system: spatial planning in Sweden. Built Environment 26(1):72-81.

Schultz, L., C. Folke, and P. Olsson. 2007. Enhancing ecosystem management through social-ecological inventories: lessons from Kristianstads Vattenrike, Sweden. Environmental Conservation 34 (02):140-152. http://dx.doi.org/10.1017/S0376892907003876

Sellberg, M. 2013. Resilience in practice for strategic planning at a local government. Thesis. Stockholm University, Stockholm, Sweden.

Shaw, K. 2012. "Reframing" resilience: challenges for planning theory and practice. Planning Theory and Practice 13(2):308-312. http://dx.doi.org/10.1080/14649357.2012.677124

Shaw, K., and L. Maythorne. 2012. Managing for local resilience: towards a strategic approach. Public Policy and Administration 28 (1):43-65. http://dx.doi.org/10.1177/0952076711432578

Stockholm Resilience Centre. 2014. What is resilience? An introduction to social-ecological research. Stockholm Resilience Centre, Stockholm, Sweden. [online] URL: http://www. stockholmresilience.org/download/18.10119fc11455d3c557d6d21/1398172490555/SU_SRC_whatisresilience_sidaApril2014.pdf

Swedish Parliament. 2006. Lag (2006:544) om kommuners och landstings åtgärder inför och vid extraordinära händelser i fredstid och höjd beredskap. Swedish Parliament, Stockholm, Sweden.

United Nations Office for Disaster Risk Reduction (UNISDR). 2007. Hyogo framework for action 2005-2015: building the resilience of nations and communities to disasters. UNISDR, Geneva, Switzerland.

United Nations Office for Disaster Risk Reduction (UNISDR). 2012. Making cities resilient: my city is getting ready. UNISDR, Geneva, Switzerland. [online] URL: http://www.unisdr.org/ campaign/resilientcities/about

Wagenaar, H. 2007. Governance, complexity, and democratic participation: how citizens and public officials harness the complexities of neighborhood decline. American Review of Public Administration 37:17-50. http://dx.doi.org/10.1177/0275074006296208

Wagenaar, H. 2011. Strategies of interpretive policy research. Pages 241-274 in H. Wagenaar, editor. Meaning in action: interpretation and dialogue in policy analysis. M.E. Sharpe, Armonk, New York, USA.

Walker, B., S. Carpenter, J. Anderies, N. Abel, G. S. Cumming, M. Janssen, L. Lebel, J. Norberg, G. D. Peterson, and R. Pritchard. 2002. Resilience management in social-ecological systems: a working hypothesis for a participatory approach. Conservation Ecology 6(1): 14. [online] URL: http://www. consecol.org/vol6/iss1/art14/

Walker, B., and D. Salt. 2006. Resilience thinking: sustaining ecosystems and people in a changing world. Island Press, Washington, D.C., USA.

Walker, B., and D. Salt. 2012. Resilience practice: building capacity to absorb disturbance and maintain function. Island Press, Washington, D.C., USA. http://dx.doi.org/10.5822/978-1-61091-231-0

Walker, B., and F. Westley. 2011. Perspectives on resilience to disasters across sectors and cultures. Ecology and Society 16(2): 4. [online] URL: http://www.ecologyandsociety.org/vol16/iss2/ art4/

Wilkinson, C. 2012a. Urban resilience: what does it mean in planning practice? Planning Theory and Practice 13(2):319-324. http://dx.doi.org/10.1080/14649357.2012.677124

Wilkinson, C. 2012b. Social-ecological resilience: insights and issues for planning theory. Planning Theory 11(2):148-169. http:// dx.doi.org/10.1177/1473095211426274

Wilkinson, C. 2012c. Social-ecological resilience and planning: an interdisciplinary exploration. Dissertation. Stockholm University, Stockholm, Sweden.

Wilkinson, C., L. Porter, and J. Colding. 2010. Metropolitan planning and resilience thinking: a practitioner's perspective. Critical Planning 17:25-39.

Wilkinson, C., and H. Wagenaar. 2012. Enacting resilience: a performative account of governing for urban resilience. Paper IV in C. Wilkinson, editor. Social-ecological resilience and planning: an interdisciplinary exploration. Dissertation. Stockholm University, Stockholm, Sweden.

World Summit on Sustainable Development (WSSD), and UN Department of Public Information. 2003. Johannesburg declaration on sustainable development and plan of implementation of the World Summit on Sustainable Development: the final text of agreements negotiated by governments at the World Summit on Sustainable Development, 26 August-4 September 2002, Johannesburg, South Africa. United Nations Department of Public Information, New York, New York, USA. 
Appendix 1. Official municipal documents

Here, we present a list of the official municipal documents that we reviewed in this study. See Sellberg (2013) for a more detailed description of the document review.

Table A1.1. List of official documents of Eskilstuna municipality reviewed in this study.

\begin{tabular}{|c|c|c|}
\hline Document & Year & Explanation \\
\hline Environmental policy & 2002 & $\begin{array}{l}\text { Steering document. Ambitions and goals for the } \\
\text { municipal organization, as well as the } \\
\text { geographical area. }\end{array}$ \\
\hline $\begin{array}{l}\text { Policy for a sustainable } \\
\text { development - Action program } \\
\text { with environmental and public } \\
\text { health targets }\end{array}$ & 2002 & $\begin{array}{l}\text { Steering document with both binding and } \\
\text { guiding sections. An umbrella document that sets } \\
\text { the direction of many other more narrow-scoped } \\
\text { plans. Local Agenda } 21 \text { program. }\end{array}$ \\
\hline Comprehensive plan & 2005 & $\begin{array}{l}\text { Spatial plan that sets the direction for long-term } \\
\text { land and water usages and steers detailed } \\
\text { physical planning. Mandatory by Swedish law. } \\
\text { In the process of being replaced by a new plan in } \\
2013 \text {. }\end{array}$ \\
\hline $\begin{array}{l}\text { Extended comprehensive plan for } \\
\text { a specific area: "Stadsbygden" }\end{array}$ & 2005 & $\begin{array}{l}\text { Addition to the comprehensive plan for a } \\
\text { specific area. }\end{array}$ \\
\hline $\begin{array}{l}\text { Extended comprehensive plan for } \\
\text { a specific area: "Mälarstranden" }\end{array}$ & 2005 & $\begin{array}{l}\text { Addition to the comprehensive plan for a } \\
\text { specific area. }\end{array}$ \\
\hline Energy plan & 2006 & $\begin{array}{l}\text { Steering document, a sector plan. Now replaced } \\
\text { by the Climate plan. }\end{array}$ \\
\hline Water plan & 2006 & $\begin{array}{l}\text { Steering document, a sector plan. Based on the } \\
\text { EU framework directive on water. }\end{array}$ \\
\hline Plan of green areas in cities & 2006 & $\begin{array}{l}\text { Elaboration of the comprehensive plan and } \\
\text { functions as a basis for detailed physical } \\
\text { planning. }\end{array}$ \\
\hline Nature conservation plan & 2006 & $\begin{array}{l}\text { Steering document, a sector plan. Functions as a } \\
\text { basis for detailed physical planning. }\end{array}$ \\
\hline $\begin{array}{l}\text { Plan for handling of residue } \\
\text { material }\end{array}$ & 2007 & $\begin{array}{l}\text { Steering document, the municipal waste } \\
\text { management plan. Mandatory by Swedish law. }\end{array}$ \\
\hline Local area work & 2007 & $\begin{array}{l}\text { Report and evaluation of the project for working } \\
\text { with local influence, participation, employment } \\
\text { and integration in certain chosen areas. }\end{array}$ \\
\hline Ecolo & 2010 & Analysis of external consultant. \\
\hline Annual report & 2011 & $\begin{array}{l}\text { Report on the municipality's achievements } \\
\text { regarding goals of sustainable development and } \\
\text { efficiency in the organization. }\end{array}$ \\
\hline Climate plan & 2012 & $\begin{array}{l}\text { Steering document, a sector plan, and replacing } \\
\text { the Energy plan. }\end{array}$ \\
\hline
\end{tabular}


Traffic plan - strategy and action program

Guide to the local food How we work with climate and environment in Eskilstuna municipality

Crisis management plan for extraordinary or severe events in peace times and during increased preparedness 2012-2015

Action plan for contaminated areas - draft
2012 Steering document, a sector plan. Two separate documents, with the overall strategy and concrete actions, respectively.

2012 Information material from the municipality.

2012 Information material from the municipality.

2012 Steering document for part of the crisis management work in the municipality, excluding e.g. preventive work.

2012 Steering document, a sector plan. Still a draft. 


\section{Appendix 2. Eskilstuna's initial resilience assessment}

Here we present a more detailed description of Eskilstuna's initial resilience assessment. In the end of this project they decided to continue with a deepened resilience assessment focusing on food, but it has not been part of this study.

In 2011, two strategic environmental planners at the municipality, Lars Wiklund and LarsErik Dahlin, contacted the Stockholm Resilience Centre to initiate a collaboration. They presented the idea to one of the Municipal Commissioners and later, the municipal council gave their approval. Performing a resilience assessment was seen as a new approach to the municipality's work with sustainable development. The aim of the project, as expressed by the planners, was that it would lead to new, resilience-building strategies in the long-term planning of the municipality.

The resilience assessment process included five planning meetings, a two-day workshop, and a report, documenting the workshop (Table A2.1). The first planning meeting was in August 2011 and the final report was finalized in September 2013. During the planning process, Eskilstuna municipality was also used as a case during a three-day course on resilience assessments at the Stockholm Resilience Centre (Table A2.1). Both Lars Wiklund and LarsErik Dahlin took part in the course, which was used as a pilot study to test our ideas about the scope of the assessment. The core planning team included the two strategic environmental planners, Lars Wiklund and Lars-Erik Dahlin, Cathy Wilkinson and My Sellberg from Stockholm Resilience Centre, and Louise Hård af Segerstad, research communicator at Albaeco. Cathy Wilkinson was the project manager. For the initiators, this project was a first step, wherefore they did not invite any external actors. About 40 civil servants and politicians were invited to the workshop from all the different departments and companies of the municipality. In the end, 23 people participated and only one was a politician. Afterwards, they evaluated the project to see if they would take it further and involve more different stakeholders.

During the planning process, the scope of the resilience assessment was determined and the workshop was planned more in detail. The strategic environmental planners especially requested the resilience assessment to target the resilience of four areas of the municipality (water supply, food supply, employment and transports) to the threats of global financial crises, climate change and energy crises (Fig. 3). They also requested an exploration of how the planetary boundaries (Rockström et al. 2009) would impact the focal systems. Furthermore they wanted the economic, social and environmental dimensions to be taken into account when resilience of the focus areas was being assessed ("So what" in Fig. 3). The project manager laid out the overall structure of the resilience assessment (Fig. 3): "resilience of what" and "to what", drawing on section 1.1-1.3 in the workbook, "so what", which looked at impacts of the threats, and "now what", which explored different strategies for resilience and implications for governance. "So what" and "now what" was based on Paul Ryan's experience as an expert practitioner on resilience assessments. In this sense, this resilience assessment was based on the Resilience Assessment Workbook (Resilience Alliance 2010), but it was also influenced by the resilience work in Luleå municipality 
(Wilkinson 2012a), the Arctic Resilience Assessment (Cathy Wilkinson, personal communication, February 2013), and Paul Ryan's work.

The workshop consisted of a mix of presentations, e.g. on resilience thinking, resilience assessments, ecosystem services and planetary boundaries, and group work (workshop agenda in Appendix 4 in Sellberg 2013). The participants were divided into four working groups, one for each focus area, and went through four different exercises to increase the understanding of the focal systems, potential impacts of large-scale threats and to spark ideas on measures:

1. Historical timeline exercise: drawing on section 1.4 in the workbook, but doing parallel timelines for each focus area in different colors (in the foreground of Fig. 4). The exercise was followed by a discussion on possible management eras.

2. Discussion of system dynamics: using the figure of regime shifts in Bellwood et al. (2004) as a metaphor to discuss their focal systems as dynamic systems with possible alternate stable states. This exploration related to section 2.2-2.3 in the workbook.

3. Impacts of crises: using a matrix with each of the specific threats to brainstorm possible consequences for the focal area in social, economic and ecological dimensions.

4. Strategies for resilience: using a list of strategies for general resilience (Appendix 1 in Sellberg 2013), developed by Cathy Wilkinson and based on Wilkinson (2012b), to identify existing and future measures for each strategy related to their focal system. This list incorporates the attributes of general resilience in section 3.3 in the workbook, as well as the stewardship strategies in section 5.2.

Table A2.1. Activities and participants of the Eskilstuna's initial resilience assessment

\begin{tabular}{|c|c|c|}
\hline Time & Activity & Participants \\
\hline Aug 2011 & $\begin{array}{l}\text { Initial meeting with } \mathrm{SRC}^{\dagger} \text { and } \mathrm{SEI}^{\dagger} \\
\text { researchers. }\end{array}$ & $\begin{array}{l}\text { Lars Wiklund, Lars-Erik Dahlin, } \\
\text { Louise Hård af Segerstad (Albaeco), } \\
\text { Cathy Wilkinson (SRC), two } \\
\text { researchers from SEI and SRC }\end{array}$ \\
\hline Feb 2012 & Planning meeting in Eskilstuna. & $\begin{array}{l}\text { Lars Wiklund, Lars-Erik Dahlin, Cathy } \\
\text { Wilkinson }\end{array}$ \\
\hline May 2012 & $\begin{array}{l}\text { PhD-course about the resilience } \\
\text { assessment at SRC, using Eskilstuna } \\
\text { as a case. }\end{array}$ & $\begin{array}{l}\text { Lars Wiklund, Lars-Erik Dahlin, } \\
\text { Cathy Wilkinson, Louise Hård af } \\
\text { Segerstad, My Sellberg (SRC), course } \\
\text { participants }\end{array}$ \\
\hline Sep 2012 & $\begin{array}{l}\text { Planning meeting at the SRC: the } \\
\text { focus areas were determined. }\end{array}$ & $\begin{array}{l}\text { Lars Wiklund, Lars-Erik Dahlin, Cathy } \\
\text { Wilkinson, Louise Hård af Segerstad, } \\
\text { My Sellberg }\end{array}$ \\
\hline Oct 2012 & $\begin{array}{l}\text { Planning meeting in Eskilstuna: 1) } \\
\text { the specific threats were determined, } \\
\text { 2) a rough plan of the different } \\
\text { workshop components, and 3) } \\
\text { establishment of the project so far } \\
\text { with the head of the Strategic } \\
\text { Environmental Department, as well } \\
\text { as two other planners. }\end{array}$ & $\begin{array}{l}\text { Lars Wiklund, Lars-Erik Dahlin } \\
\text { Cathy Wilkinson, Louise Hård af } \\
\text { Segerstad, My Sellberg, Head of the } \\
\text { Strategic Environmental Department, } \\
\text { two other planners }\end{array}$ \\
\hline
\end{tabular}


Feb 2013 Planning meeting in Eskilstuna: detailed workshop planning.

Feb 2013 2-day workshop in Eskilstuna: education in resilience thinking and group work.

Sep 2013 Report with workshop documentation and reflections on the project
Lars Wiklund, Lars-Erik Dahlin

Louise Hård af Segerstad, My Sellberg

Lars Wiklund, Lars-Erik Dahlin

Cathy Wilkinson, Louise Hård af

Segerstad, My Sellberg, 21 other participants (civil servants +1 local politician)

Louise Hård af Segerstad, Cathy

Wilkinson, My Sellberg

\footnotetext{
$\uparrow$ Stockholm Resilience Centre

† Stockholm Environmental Institute
} 


\section{Appendix 3. Semistructured interviews}

In this section, we describe how we conducted the interviews in this study. The interviews were based on Kvale and Brinkmann (2009), as well as Wagenaar (2011). They were semistructured, meaning that they followed an interview guide with different topics, but remained flexible for unplanned questions (Kvale and Brinkmann 2009:130). The topics usually started with a broad question, followed by suggestions on more specific follow-up questions (see examples below). Sometimes the interviewees answered many questions at once, but then the interview schedule was used to ensure that all relevant topics had been discussed. During the interviews, we were concerned both with building a relationship with the interviewees and receiving high quality interview data, for example by getting detailed and spontaneous descriptions by the interviewees (Kvale and Brinkmann 2009, Wagenaar 2011).

Six informants were interviewed and three of them twice, before and after the workshop. These were the two initiating planners and the crisis manager. The reason was to gather more information on the background of the project, the current work with sustainable development and crisis management, as well as their expectations on the resilience assessment. In total, we conducted nine interviews, seven face-to-face of approximately 1-1,5 hours each, and two telephone interviews of approximately 15-30 minutes each while taking notes. The telephone interviews were with the Municipal Commissioner involved in initiating the project, and a spatial planner working in the comprehensive planning process. The interview schedule was adapted to fit the specific interview, depending on the interviewee's position and expected knowledge, where we were in the resilience assessment process, and where we were in the research process. The last six interviews, conducted shortly after the workshop, were used specifically to test earlier interpretations and clarify questions that had emerged earlier in the project. All the face-to-face interviews were recorded and transcribed. Afterwards, the interviewees had the possibility to comment on the transcriptions. While reading through the transcriptions (including the transcription of the reflection session of the workshop) and notes, we wrote short memos between the quotes as a part of a preliminary analysis, or sense making, of the findings.

\section{Examples of interview questions}

These are examples of the interview questions, translated from Swedish. Questions 1-5 were used in interviews with the strategic environmental planners before the workshop (in October 2012), and 6-8 in interviews after the workshop (in February 2013).

1. Can you tell me the story of how you decided to work with resilience?
a. When did you hear about it the first time?
b. How did it happen that you sent the first e-mail to SRC?
c. What was the catalyzer?
d. Follow-up questions: Who did what? When? What happened before? What happened after?


2. What are your expectations of the resilience assessment?

a. Expectations on the workshop and how it could influence the work in the future.

b. Expectations on how resilience could be used to market Eskilstuna municipality.

c. Worries before the workshop? What are the risks?

d. What is it in the resilience thinking that you find especially interesting?

e. Personal professional goals, and if the resilience assessment could assist you in reaching them.

3. How do you think resilience relates to sustainable development?

a. Were you there when sustainable development entered the municipality's agenda?

b. What do you think sustainable development has contributed to the planning work? Examples (positive and negative) of how it has affected your work.

c. Do you think sustainable development has been watered down and is that why resilience is interesting?

d. What do you relate to a "sustainable municipality"?

e. What do you relate to a "resilient municipality"?

f. What differs between a sustainable and a resilient municipality?

4. Is there any relation to the municipality's crisis management work?

a. How do you think they are connected?

5. Personal background, education and interests, etc. (if I would like to ask more about it).

6. What is it that is special about resilience? What do you think it adds to what you are already doing in the municipality?

a. How does it relate to the municipality's work with sustainable development?

b. How does it relate to the municipality's work with crisis management?

7. What are the challenges with using resilience thinking and doing a resilience assessment?

8. What potential has the resilience assessment in changing current municipal planning and in what way could it change/in what direction? 
Appendix 4. Evaluation of the resilience assessment workshop

This evaluation form was given to the participants of the resilience assessment workshop in Eskilstuna, in February 2013. Questions are translated from Swedish. However, the actual form also included the aim of the evaluation and e.g. contact details of the researchers.

1) Circle the number that best corresponds to your knowledge of resilience before this workshop ( $1=$ did not know the concept at all, $5=$ thorough understanding of the concept).

$\begin{array}{lllll}1 & 2 & 3 & 4 & 5\end{array}$

2a) Has the workshop been organized in a good way? $\square$ Yes $\quad \square$ Partly $\quad \square$ No

2b) What could have been improved?

3a) Have the presentations had an appropriate level of difficulty?

$\square$ Yes $\quad \square$ Partly $\quad \square$ No

3b) Was there some part that was more difficult to understand?

4a) What new insights have you gained from the workshop?

4b) In what ways could they be useful in your daily work?

5) What is new with the resilience assessment, compared to the current municipal planning?

6) Is there some part of the resilience assessment that is not suitable for usage in a municipality, or that is redundant?

7) Could the resilience assessment influence the coming municipal planning, e.g. regarding the work with sustainable development or crisis management? In that case, in what way?

8a) Is it important for the municipality to continue to work with resilience?

$\square$ Yes $\quad \square$ No $\quad \square$ Don't know

8b) What other focus areas and threats do you think are important?

8c) Would you like to be a part of a continuation of the project?

$\square$ Yes $\quad \square$ No $\quad \square$ Maybe $\quad \square$ Don’t know

Other comments: 
Appendix 5. Contributions of the resilience assessment to municipal planning

This table presents emergent themes of how the resilience assessment contributed to municipal planning and management at Eskilstuna municipality. Each theme is presented with examples from the interviews, observations and the survey to the workshop participants. Note that the themes are not disconnected, but rather influence each other in many ways. In the results section, these themes are clustered into three main categories of contributions. See also Sellberg (2013) for a more detailed description of the data analysis. (SEP=strategic environmental planner, $\mathrm{SD}=$ sustainable development.)

Table A5.1. Contributions of the resilience assessment in Eskilstuna to municipal planning, presented with examples.

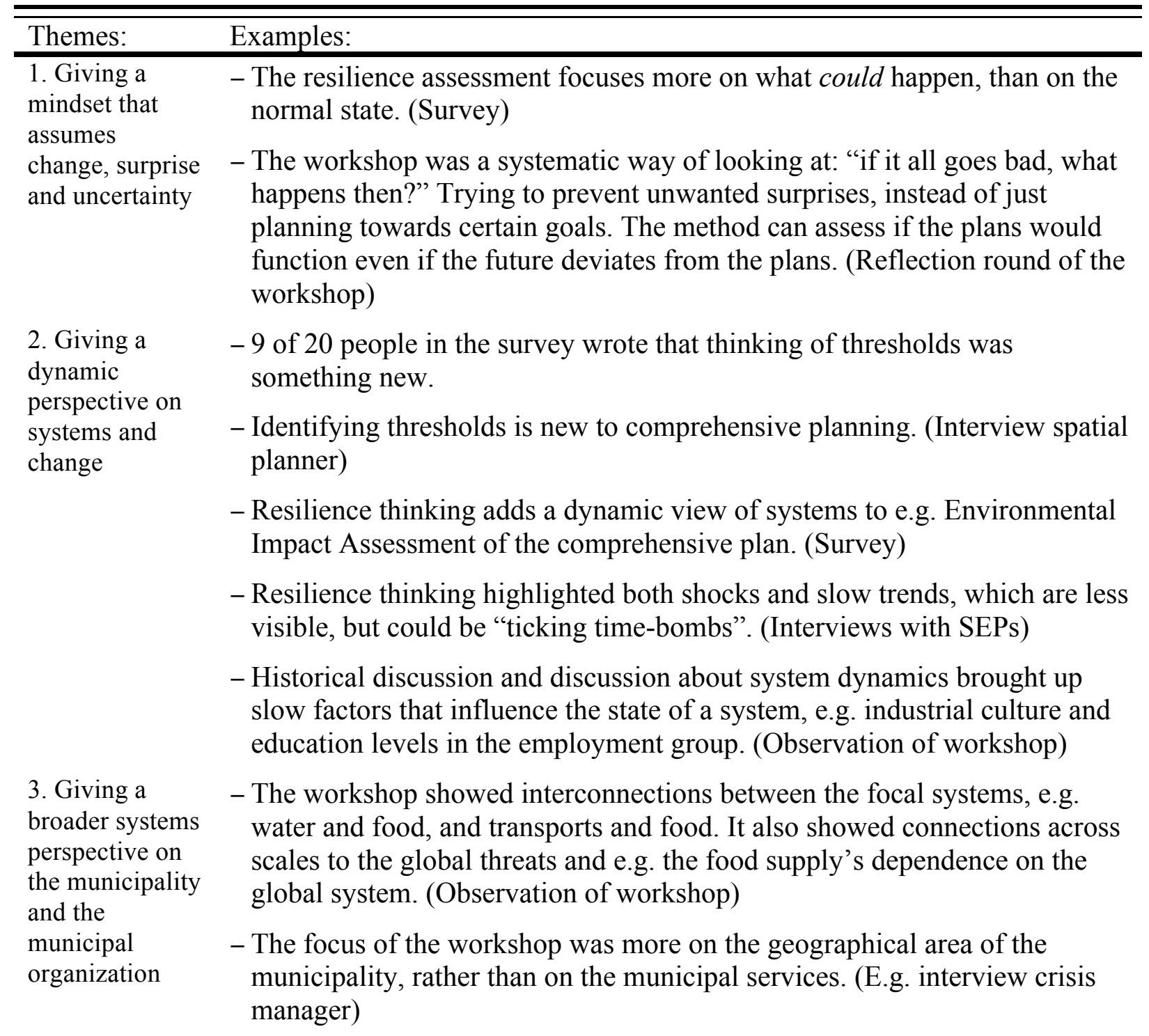




\begin{tabular}{|c|c|}
\hline Themes: & Examples: \\
\hline \multirow{6}{*}{$\begin{array}{l}\text { 4. Drawing } \\
\text { attention to } \\
\text { social- } \\
\text { ecological } \\
\text { integration }\end{array}$} & $\begin{array}{l}\text { - The resilience assessment dealt with the underlying events, even though } \\
\text { they might not have a direct effect on municipal services, rather than the } \\
\text { secondary consequences of those events. (Interview crisis manager) }\end{array}$ \\
\hline & $\begin{array}{l}\text { - The workshop and a systems approach facilitated understanding of } \\
\text { interactions and mutual dependencies between different parts of the } \\
\text { municipality, and the interconnectedness of issues. This invites to } \\
\text { cooperation, since we cannot solve an issue by ourselves, and motivates } \\
\text { working together, towards common goals, or away from undesired } \\
\text { trajectories. (Interviews SEP1, SEP3 and crisis manager) }\end{array}$ \\
\hline & $\begin{array}{l}\text { - Resilience thinking gives attention to the ecological dimension and the } \\
\text { importance of biodiversity. But, it frames this as a critical part of peoples' } \\
\text { welfare, by using concepts such as ecosystem services. (Interviews SEP1 } \\
\text { and SEP2) }\end{array}$ \\
\hline & $\begin{array}{l}\text { - The workshop was used to frame both ecological and social issues of } \\
\text { concern, e.g. unemployment. (Observations of process) }\end{array}$ \\
\hline & $\begin{array}{l}\text { - Working with a broad, and also historical, perspective indirectly leads to } \\
\text { more understanding of our ecological dependence, since then the context of } \\
\text { our current situation becomes clearer. (Interview SEP2) }\end{array}$ \\
\hline & $\begin{array}{l}\text { - Resilience thinking increases our understanding of how parts of the system } \\
\text { interact, both in nature, but also between people, and help us prioritize } \\
\text { what is important and not. (Interview SEP2) }\end{array}$ \\
\hline \multirow[t]{5}{*}{$\begin{array}{l}\text { 5. Facilitating } \\
\text { an integrated } \\
\text { perspective }\end{array}$} & $\begin{array}{l}\text { - "Resilience is not primarily an environmental tool, but a tool for man's } \\
\text { ability to survive and adapt to have a good life" (Survey). Looking for } \\
\text { consequences of global crises on economic and social systems was seen as } \\
\text { very important too (Interviews SEPs). }\end{array}$ \\
\hline & $\begin{array}{l}\text { - It is difficult to avoid a broader discussion at a resilience assessment and a } \\
\text { holistic perspective comes more automatically. (Interview SEP2) }\end{array}$ \\
\hline & $\begin{array}{l}\text { - Resilience has a broader scope than comprehensive planning, which } \\
\text { focuses on land use. (Interview spatial planner) }\end{array}$ \\
\hline & $\begin{array}{l}\text { - Resilience thinking provides planners with concepts and models that } \\
\text { connect different areas, which means better possibilities to find solutions } \\
\text { with positive synergy effects. (Interview SEP2) }\end{array}$ \\
\hline & $\begin{array}{l}\text { - The workshop was training in thinking every part of SD (survey) and it } \\
\text { lifted holistic thinking within SD because of discussing all the dimensions } \\
\text { in an integrated manor (Interview SEP1). }\end{array}$ \\
\hline
\end{tabular}




\begin{tabular}{ll}
\hline \hline Themes: & Examples: \\
\hline $\begin{array}{l}\text { 6. Framing a } \\
\text { discussion of } \\
\text { planning for } \\
\text { long-term }\end{array}$ & - A more holistic way of thinking, showing interconnections between \\
(global) threats & different parts, leads to less risk of future threats falling in between \\
with many & responsibilities in the municipality. (Interview SEP1) \\
uncertainties & term threats. (Survey and reflection session of workshop) \\
& - The workshop enabled a rare occasion to discuss these issues together and \\
& zoom out on the problem situation. (Interview Municipal Commissioner) \\
& - System dynamics helps visualizing the threats and their long-term \\
& consequences to society, as well as society's vulnerabilities. (E.g. \\
& Interview SEP3) \\
& - Threshold effects frame surprise and need to discuss worst-case scenarios \\
& and take drastic effects of crisis into account. Potential irreversibility of \\
& threshold effects framed a sense of urgency, especially for ecological \\
& changes (Interview SEP1). As one of the participants put it: "the ecological \\
& ball, it's on its way over" (Reflection session of workshop).
\end{tabular}

7. Providing a common language and a common tool/method

8. Helping to explore consequences of crisis in the system
- System dynamics provided a common language to look at change in a new, more dynamic way and "strategies for resilience" was a new way of systematizing strategies and provided a new and common language to talk about different strategies. Part of the thinking is there already, but not with those labels. (Observations and interview crisis manager)

- A broad concept that bridged different sectors makes it possible to engage people from many different perspectives. (Interview SEP3)

- Talk on ecosystem services also gave new common concepts. (Observation of workshop and reflection session)

- Strengthened the thinking of the municipality as a group with a shared goal by providing a common tool/method, which demands working across sectors (Reflection session of workshop), and could be applicable on all the different departments of the municipality (Interview crisis manager).

- Resilience thinking provides a common language and mindset that could facilitate the discussion about sustainability and avoiding it to be watered down. (Interview SEP2)

- The workshop was a free zone where you could think more wildly and freely, e.g. about consequences of climate change, or worst-case scenarios in general (Interview with SEP1). It also highlighted uncertainties regarding their consequences (Observation of workshop).

- Historical discussion on past crises (e.g. oil crisis in the 70's) gave understanding of the current system's response to crisis. (Observation of workshop)

- The exercise on consequences of threats gave a deeper exploration of potential consequences, both positive and negative and in different 


\begin{tabular}{|c|c|}
\hline Themes: & Examples: \\
\hline & $\begin{array}{l}\text { dimensions (social, ecological and economical) and generated new } \\
\text { discussions on e.g. the impact of climate change on employment. } \\
\text { (Observation of workshop and reflection session) } \\
\text { - Discussion on system dynamics framed need to identify risks of unwanted } \\
\text { threshold effects in society. (Survey and reflection session) } \\
\text { - The resilience assessment is a systematic identification of vulnerabilities } \\
\text { (survey) and a tool to think more long-term regarding the ecological } \\
\text { dimension (reflection session of workshop), e.g. thinking about how } \\
\text { ecosystem services would be impacted by crises (Observation of } \\
\text { workshop). }\end{array}$ \\
\hline $\begin{array}{l}\text { 9. Highlighting } \\
\text { certain } \\
\text { strategies }\end{array}$ & $\begin{array}{l}\text { - Going through "strategies for resilience" meant identifying strategies with } \\
\text { few existing actions, e.g. learning from crises and adaptive management, } \\
\text { and identifying strategies that were only informal, e.g. learning from crises, } \\
\text { social-ecological memory and local knowledge. (Workshop output) }\end{array}$ \\
\hline \multirow{7}{*}{$\begin{array}{l}\text { 10. One way of } \\
\text { operationalizing } \\
\text { SD }\end{array}$} & $\begin{array}{l}\text { - "Strategies for resilience" highlighted new strategies to existing crisis } \\
\text { management, e.g. transformability and nurturing diversity, especially } \\
\text { ecological diversity. (Interview crisis manager) }\end{array}$ \\
\hline & $\begin{array}{l}\text { - Resilience thinking highlighted strategies of e.g. higher self-sufficiency } \\
\text { and increasing local food production, better capacity to cope with } \\
\text { (dramatic) change, more strategic foresight and better prevention of crisis, } \\
\text { and planning to be able to deal with different scenarios. (Interviews SEPs) }\end{array}$ \\
\hline & $\begin{array}{l}\text { - The sustainability concept is like an umbrella and resilience is a tool, or an } \\
\text { approach within that. (E.g. interviews SEPs) }\end{array}$ \\
\hline & $\begin{array}{l}\text { - You give a more concrete content to SD by going through the method with } \\
\text { its different steps, ending in strategies. (Interview SEP1) The workshop } \\
\text { meant working through it in more detail to explore what SD could mean. }\end{array}$ \\
\hline & $\begin{array}{l}\text { - Resilience thinking clarifies the meaning of SD, fills the SD concept with } \\
\text { content, making it more comprehensible. (Interview SEP2) }\end{array}$ \\
\hline & $\begin{array}{l}\text { - One way of actually trying to translate SD without jumping down into the } \\
\text { sector plans. (Interview SEP2) }\end{array}$ \\
\hline & $\begin{array}{l}\text { - The resilience assessment does not bring any new goals and does not } \\
\text { decide what is desirable, but it could be used when planning to reach } \\
\text { certain strategic goals in the municipality. (Observations and interview } \\
\text { SEP3) }\end{array}$ \\
\hline
\end{tabular}

11. Clarifying a - The resilience assessment, and thinking of alternate regimes, facilitated a common goal clarifying discussion about the desired state of the focal system, as well as picture the undesired. This facilitates the generation of a common, and clarified, long-term goal picture. (Observations of workshop and interview SEP3, SEP1)

- Resilience thinking is one out of several things that would facilitate 


\begin{tabular}{|c|c|}
\hline Themes: & Examples: \\
\hline \multirow{6}{*}{$\begin{array}{l}\text { 12. Helping to } \\
\text { assess current } \\
\text { work of the } \\
\text { municipality } \\
\text { relative to their } \\
\text { SD goals }\end{array}$} & $\begin{array}{l}\text { development of a vision of a more sustainable society. It might help us to } \\
\text { see what the holistic picture could look like and how we should live within } \\
\text { planetary boundaries. (Interview SEP1, SEP3) }\end{array}$ \\
\hline & $\begin{array}{l}\text { - The ideal of the resilient society is more about being resistant to change } \\
\text { and being able to respond to changes rapidly if needed. (Interview SEP3) }\end{array}$ \\
\hline & $\begin{array}{l}\text { - A common knowledge/idea of which the most important thresholds are that } \\
\text { we really should not pass, helps formulate the common picture of the goal, } \\
\text { since then we have to stop before the thresholds. (Interview SEP3) }\end{array}$ \\
\hline & - A model/tool for analyzing and working with sustainability. (Survey) \\
\hline & $\begin{array}{l}\text { - The workshop highlighted interconnections between focus areas, e.g. when } \\
\text { mapping consequences of threats connected to the focus area. This } \\
\text { connected societal functions into a more holistic assessment. (Interview } \\
\text { SEP2) }\end{array}$ \\
\hline & $\begin{array}{l}\text { - Getting a more holistic picture of the work of the municipality shows if } \\
\text { some aspect is missing relative to the SD goals, and what type of threat that } \\
\text { implies. A resilience assessment could be a tool to keep holistic } \\
\text { perspective in planning when it comes to concrete decision-making, } \\
\text { complementing e.g. Environmental Impact Assessments. (Interview SEP2) }\end{array}$ \\
\hline \multirow{5}{*}{$\begin{array}{l}\text { 13. Providing } \\
\text { new arguments } \\
\text { for taking } \\
\text { action }\end{array}$} & $\begin{array}{l}\text { - "Strategies of resilience" was used as a framework to assess existing } \\
\text { actions and identify prioritized areas for future actions. (Observation of } \\
\text { workshop) }\end{array}$ \\
\hline & $\begin{array}{l}\text { - Resilience thinking could help assessing how far the municipality has } \\
\text { reached relative to their SD goals, by assessing current measures and if } \\
\text { they are enough. The focus is more on long-term goals, conditions for } \\
\text { sustainability and planetary boundaries, than optimization of current } \\
\text { processes. (Interview SEP2) }\end{array}$ \\
\hline & $\begin{array}{l}\text { - Understanding how different parts cooperate and interact in e.g. social- } \\
\text { ecological systems might also generate recognition of investments in } \\
\text { measures that previously were seen as luxury, e.g. new investments in } \\
\text { ecosystems to be able to fix other problems, since they support each other. } \\
\text { (Interview SEP2) }\end{array}$ \\
\hline & $\begin{array}{l}\text { - (Scientifically) identified thresholds would be important basis for decision- } \\
\text { making. If development is seen as steps with thresholds and alternate } \\
\text { regimes, rather than linear trends that we could adapt to, that would be a } \\
\text { strong argument for investing more resources in avoiding undesired states. } \\
\text { Motivating measures that previously were seen as luxury. (Interview } \\
\text { SEP1) }\end{array}$ \\
\hline & $\begin{array}{l}\text { - System dynamics could also highlight slow negative trends that could be } \\
\text { ticking time bombs, such as a growing discontent because of segregation }\end{array}$ \\
\hline
\end{tabular}




\begin{tabular}{ll}
\hline \hline Themes: & Examples: \\
\hline & and eutrophication, providing stronger basis for taking action. (Interviews \\
& SEPs) \\
& - The image of the "resilient city" makes it more difficult to argue for \\
& Business-as-Usual. (Interview SEP3) \\
14. Facilitating & - The workshop was partly about daring to think more freely, letting go of \\
transformation & margins of expenditure, etc. Thinking more broadly than your own role, \\
and innovation & $\begin{array}{l}\text { and about how we must act in a wider perspective. (Interview spatial } \\
\text { planner) } \\
-\end{array}$ \\
& Resilience thinking is a way of coping that bridges over to a more \\
& old paradigm of more extrinsic values that did not succeed to generate any \\
& real solutions anymore. The method could open up to slowly transitioning \\
& to a more sustainable society. (Interview SEP2) \\
- & System dynamics framed the transformation of the transport system in a \\
& new way, and subsequently showed some of the obstacles to \\
& transformation. (Observation of workshop)
\end{tabular}

